\title{
Macro Coumarins as Novel Antioxidants
}

\author{
DUNYA L. AL-DUHAIDAHAWI ${ }^{*}$, YASAMEEN K. AL-MAJEDY², \\ HIBA H. IBRAHEEM ${ }^{2}$, ABDUL AMIR H. KADHUM ${ }^{3}$ and AHMED A. AL-AMIERY²
}

'Pharmaceutical Chemistry Department, College of Pharmacy, University of Kufa, AL-Najaf 31001, Iraq. ${ }^{2}$ Branch of Chemistry, Department of Applied Science, University of Technology (UOT), Baghdad 10001, Iraq.

${ }^{3}$ Department of Chemical and Process Engineering, University Kebangsaan Malaysia (UKM), Bangi, Selangor 43000, Malaysia.

${ }^{*}$ Corresponding author E-mail: dunyal.mohammed@uokufa.edu.iq

http://dx.doi.org/10.13005/ojc/340544

(Received: March 29, 2018; Accepted: August 25, 2018)

\begin{abstract}
The present work pointed at the design and synthesis of novel coumarin compounds as antioxidants. The alteration of 4-hydroxycoumarin by several reaction levels was performed to generate destination compounds. Spectroscopic methods like Infrared Spectra FT-IR, ${ }^{1} \mathrm{H}-\mathrm{NMR}$ and ${ }^{13} \mathrm{CNMR}$, elemental analysis techniques, melting point, and thin layer chromatography defined the structure of the prepared compounds. The antioxidant activities of individual compounds were tested against stable free radical 1,1-Diphenyl-2-picrylhydrazyl radical (DPPH), hydrogen peroxide $\left(\mathrm{H}_{2} \mathrm{O}_{2}\right)$ and FRAP (ferric reducing antioxidant power) and the results were related to the Gallic acid, ascorbic acid and Trolox as standards. The effects revealed that most of the syntheses presented greater activity as an antioxidant than the standards in different concentration range. The distinguished competence inactivating action was observed for compound $2(86.3 \pm 1 \%)$ followed by compounds $3(85 \pm 0.5 \%)$ using DPPH method. The antioxidant mode of action of the prepared compounds was also investigated.
\end{abstract}

Keywords: Antioxidant, DPPH, FRAP hydroxycoumarin $\mathrm{H}_{2} \mathrm{O}_{2}$ in activators, Macromolecules.

\section{INTRODUCTION}

Coumarin is a simple molecule that originates from lactones family. As it possesses a benzopyrone system, it isolates itself from plants. Also, it can undergo total synthesis that is conducted in the laboratory. Furthermore, coumarin can be synthesized from many established chemical reactions. Although coumarins can be obtained from various natural resources, new coumarin derivatives are continuously being discovered and synthesized on regular basis.

Coumarin and coumarin-related compounds have demonstrated much popularity in their used way back for a long time. This is because these compounds have shown significant potential in the production of therapeutic products. They are known for a variety of uses: physiological, antimicrobial ${ }^{1,2}$, antioxidant ${ }^{3,5}$, anti-inflammatory ${ }^{6,7}$, anticoagulant and antitumor ${ }^{8}$ activities. In recent years, there is much attention in the search for antioxidants from natural, industrial sources. As antioxidants inhibit and scavenge radicals, they play an important role in protecting humans from infections and degenerative diseases. As such antioxidants can be defined as any substrate that significantly delays or prevents oxidation. According to 9 in comparison with an 
oxidizable substrate (lipid, protein, carbohydrate, or DNA) only low concentration of antioxidant is required to delay or prevent numerous diseases conditions such as swelling, carcinogenesis, atherogenesis and also in the aging process as well as after virulent exposure to xenobiotic ${ }^{10-12}$.

Interest in the discovery of new antioxidant agents has surmounted increased, since the implication of oxidative damages in many pathology cases. The other class of compounds that has caught much attention is polyphenols. This group of molecules comprises flavonoids Flavonoids like flavonols, chalcones, flavanones, flavones, flavan-3-ols in addition to lignins, tannins and tocopherols and phenolic acid ${ }^{13}$. However, the flavonoids constitute the largest group of phenolic compounds with a wide range of biochemical and physiological actions like an antioxidant and free radical inactivates characteristics ${ }^{14}$. Furthermore, the phenolic molecules can serve as antioxidants by coordinating metal ions, counteracting the generation of radicals and stimulating the antioxidant endogenous system forward ${ }^{15}$. Originally, we were utilizing 4-hydroxycoumarin as a preliminary substance and all the integrated coumarins are manifested in Scheme 1.<smiles>N#CCC#N</smiles>
4-Hydroxycoumari Malononitril 4-bromobenzyldehyde<smiles>N#CC1=C(N)Oc2c(c(=O)oc3ccccc23)C1c1ccc(Br)cc1</smiles>

(1)<smiles></smiles>

(2)<smiles>COC(=O)C1=C(N)Oc2c(c(=O)oc3ccccc23)C1c1ccc(Br)cc1</smiles>

(4)

(3)

Scheme 1. Transformation series of the prepared compounds Chemicals and Environments: $a=$ Tetrabutylammonium bromide (TBAB)/reflux; $b=$ diammonium hydrogen phosphate (DAHP)/reflux; $c=$ hydrolysis; $d$ = benzene/ reflux; $e_{=} \mathrm{H}_{2} \mathrm{SO}_{4} /$ reflux

\section{EXPERIMENTAL}

\section{General Chemistry}

The compounds utilized throughout synthesis were provided by Sigma-Aldrich (Selangor, Malaysia). The infrared ranges were achieved on a Nicolet 6700 FT-IR spectrophotometer (Thermo Nicolet Corp., Madison, WI, USA), and the data are displayed in $\mathrm{cm}^{-1}$. NMR bands were verified manipulating an AVANCE III $600 \mathrm{MHz}$ spectrometer (Bruker, Billerica, MA, USA), DMSO used as a solvent and the data are revealed in $\delta \mathrm{ppm}$. CHN analysis was accomplished on an Elemental analyzer Carlo Erba 1108 (Vario El III, SpA, Rodano, Italy).

\section{Chemical Synthesis}

Synthesis of 2-amino-4- (4-bromophenyl)5-oxo-4, 5-dihydropyrano [3, 2-c] chromene-3- carbonitrile (1)

\section{Tetrabutylammonium Bromide (TBAB) as catalytic} agent for synthesis of compound (1)

The reactants, 4-Hydroxy-1-benzopyran-2one (0.162 g; $10 \mathrm{mmol}$ ) with 4-bromobenzaldehyde (5 mmol), malononitrile (15 mmol) and Tetra-nbutyl ammonium bromide (10 mol \%) were agitated under reflux. Then, the combination was chilled to ambient temperature. The slurry was separated by filtration and desiccated then recrystallized from ethanol 16. Then the compound was characterized by spectroscopic and physical data yields $75 \%$, m.p $(223-225)^{\circ} \mathrm{C}$.

Diammonium Hydrogen Phosphate (DAHP) as catalytic agent for production of compound (1) In an aqueous ethanol solution (50\% 
$\left.\mathrm{H}_{2} \mathrm{O}: 50 \% \mathrm{EtOH}\right)$ totally $50 \mathrm{ml}$ starting compounds comprising 4-hydroxycoumarin (0.162 g; $10 \mathrm{mmol})$, 4-bromobenzaldehyde (10 mmol), malononitrile (12 mmol) and ammonium monohydrogen phosphate (26.4 mg, $10 \mathrm{~mol} \%$ ), were agitated for $4 \mathrm{~h}$, at ambient condition. when the reaction complete, the slurry was separated by filtration and rinsed with ethanol ${ }^{17}$. Then the compound was characterized by spectroscopic and physical data., yields $70 \%$., m.p ( $\left.225-227^{\circ} \mathrm{C}\right)$; ${ }^{1} \mathrm{H}-\mathrm{NMR}$ : $\delta 4.28$ (s, $1 \mathrm{H}, \mathrm{CH}$ ), $\delta 7.11$ and $\delta 7.83$ (dd, $2 \mathrm{H}), \delta 7.42-7.83(\mathrm{~m}, 1 \mathrm{H}, \mathrm{C}-\mathrm{H}$ aromatic ring), $\delta 8.49$ (s, $\left.\mathrm{NH}_{2}\right) ;{ }^{13} \mathrm{CNMR}$ (DMSO): 40, 58.3, 108, 116.0, 125.1, 128.1, 152.1, 160.5, 161.1 and 165.5; FT-IR: 3385.8 $\mathrm{cm}^{-1}\left(\mathrm{NH}_{2}\right), 3189.0 \mathrm{~cm}^{-1}$ (C-H aromatic), $1709.2 \mathrm{~cm}^{-1}$ $(\mathrm{C}=\mathrm{O}$, lactone $), 2213 \mathrm{~cm}^{-1}(\mathrm{C} \equiv \mathrm{N}), 1638.0 \mathrm{~cm}^{-1}(\mathrm{C}=\mathrm{C}$ aromatic); $\mathrm{CHN}$ analysis: Calcd. for $\mathrm{C}_{19} \mathrm{H}_{11} \mathrm{BrN}_{2} \mathrm{O}_{3}$ : C $57.74 \%$ H $2.81 \%$ N $7.09 \%$, Found: C $57.54 \%$ H $2.1 \%$ and $\mathrm{N} 6.91 \%$.

Synthesis of 2-amino-4- (4-bromophenyl)-5oxo-4, 5-dihydropyrano [3,2-c] chromene-3carboxylic acid (2)

Aqueous sodium hydroxide solution ( $1 \mathrm{M}$, $0.3 \mathrm{ml}$ ) was supplemented to compound (1) and the combination was warmed for $5 \mathrm{~min}$. at $140^{\circ} \mathrm{C}$. hydrochloric acid $(1 \mathrm{M}, 0.3 \mathrm{ml})$ was then added to make solution neutral under these conditions we got compound (2) at 19-20 minutes After finishing the reaction, the slurry was separated by filtration and rinsed with ethanol, 18, yields: 50\%, m.p (230$233^{\circ} \mathrm{C}$ ); ${ }^{1} \mathrm{H}-\mathrm{NMR}$ : $\delta 3.93(\mathrm{~s}, 1 \mathrm{H}, \mathrm{CH}), \delta 7.10$ and $\delta$ 7.81 (dd, $2 \mathrm{H}), \delta$ 7.32-7.82 (m, 4H, C-H aromatic), $\delta 8.5\left(\mathrm{~s}, \mathrm{NH}_{2}\right), \delta 11.0(\mathrm{~s}, \mathrm{OH})$; FT-IR: $3221\left(\mathrm{NH}_{2}\right)$, $3307 \mathrm{~cm}^{-1}(\mathrm{OH}) ; 3090.1 \mathrm{~cm}^{-1}$ (C-H aromatic), 1652 $\mathrm{cm}^{-1}\left(\mathrm{C}=\mathrm{O}\right.$, lactone), $1710 \mathrm{~cm}^{-1}(\mathrm{C}=\mathrm{O}$, carboxylic), $1625.3 \mathrm{~cm}^{-1}$ (C=C aromatic); $\mathrm{CHN}$ analysis: Calcd. for $\mathrm{C}_{19} \mathrm{H}_{12} \mathrm{BrNO}_{5}$ : C 55.09\% H 2.92\% N 3.38\%, Found :C $54.54 \% \mathrm{H} 2.5 \%$ and N 3. $1 \%$.

Synthesis of 2-amino-4- (4-bromophenyl)-5oxo-4, 5-dihydropyrano [3,2-c] chromene-3carboxylic 2-chloroacetic anhydride (3)

In $100 \mathrm{ml} \mathrm{RBF}$, (0.02 mol, $9.81 \mathrm{~g})$ of compound (2) in $4 \mathrm{ml}$ ethanol was mixed in magnetic agitator for 10 minutes. Chlor-acetyl chloride (0. 02 mole, 4 equivalent) was supplemented gradually for $1 \mathrm{~h}$, Reaction combination was maintained on stirring for 24-writhe reaction mixture was chilled, transferred into an ice water $(50 \mathrm{ml})$ including a drop of pyridine and agitated till the oil solidifies.
The crude result was filtrated, rinsed with ice-cold water and evaporated. The result was recrystallized from ethanol, yields $45 \%$, m.p $\left(244-246^{\circ} \mathrm{C}\right)$; 'H-NMR: $\delta 2.1(\mathrm{~s}, 1 \mathrm{H}, \mathrm{NH}), \delta 3.91(\mathrm{~s}, 1 \mathrm{H}, \mathrm{CH}), \delta$ 7.2 and $\delta 7.82(\mathrm{dd}, 2 \mathrm{H}), \delta$ 7.4-7.79 (m, 4H, C-H aromatic ring), $\delta 8.4\left(\mathrm{~s}, \mathrm{NH}_{2}\right)$; FT-IR: $3433-3328 \mathrm{~cm}^{-1}$ $\left(\mathrm{NH}_{2}\right), 3055.1 \mathrm{~cm}^{-1}$ (C-H aromatic), $1652 \mathrm{~cm}^{-1}(\mathrm{C}=\mathrm{O})$ $1602.9 \mathrm{~cm}^{-1}$ ( $\mathrm{C}=\mathrm{O}$, lactone); $\mathrm{CHN}$ analysis: Calcd. for $\mathrm{C}_{20} \mathrm{H}_{14} \mathrm{BrClN}_{2} \mathrm{O}_{4}$ : C $52.03 \% \mathrm{H} 3.06 \%$ N $6.07 \%$, Found: C 51.5\% H 2.88\% and N 5.81\%.

Synthesis of 7-(4-bromophenyl)-10-(chloromethyl) -6H-chromeno [3', 4': 5,6] pyrano [2,3-d][1,3] oxazine-6,8(7H)-dione (4)

To a solution of $2 \mathrm{mmol}, 0.941 \mathrm{~g}$ of compound (3) in $50 \mathrm{ml}$ of dry methanol was added concentrated sulphuric acid $(80 \mathrm{mmol})$. The combination was refluxed for (3-4) h, Following cooling; the reaction substance was transferred into an ice-water mixture. The solid particles were collected by percolation, rinsed with water and recrystallized from methanol to obtain compound (4) 19 , yields $35 \%$, m.p ( 217-219 $\left.{ }^{\circ} \mathrm{C}\right)$; ${ }^{1} \mathrm{H}-\mathrm{NMR}: \delta 3.9\left(\mathrm{~s}, 2 \mathrm{H}, \mathrm{CH}_{2} \mathrm{Cl}\right), \delta 4.4$ (s, $1 \mathrm{H}, \mathrm{CH}), \delta 7.1$ and $\delta 7.8(\mathrm{dd}, 2 \mathrm{H}), \delta 7.4-7.79(\mathrm{~m}$, $1 \mathrm{H}$ ??, C-H aromatic ring) ; FT-IR: $3181.6 \mathrm{~cm}^{-1}(\mathrm{C}-\mathrm{H}$ aromatic), 1670.6, $1612.1 \mathrm{~cm}^{-1}(\mathrm{C}=\mathrm{O}$, lactone), $1570.4 \mathrm{~cm}^{-1}$ (C=C aromatic); $\mathrm{CHN}$ analysis: Calcd. for $\mathrm{C}_{21} \mathrm{H}_{11} \mathrm{BrClNO}_{5}$ : C 53.36\% H 2.35\% N 2.96\%, Found: C 52.64\% H 2.1\% and N 1.91\%.

\section{Antioxidant activity}

(2,2-Diphenyl-1-(2,4,6-trinitrophenyl)hydrazyl) (DPPH) free radical scavenging activity

Antioxidant properties of synthesized coumarin compounds (1-4) were tested spectrophotometrically utilizing 2,2-diphenyl-1-picrylhydrazyl radical, ${ }^{20,21}$. At first, $0.1 \mathrm{~mL}$ of different strengths of prepared compounds $0.25,0.5,0.75$ and $1 \mathrm{mg} / \mathrm{ml}$ and standard ascorbic acid were combined $1 \mathrm{ml}$ of $0.2 \mathrm{mM} \mathrm{DPPH}$ solubilized in $\mathrm{CH}_{3} \mathrm{OH}$. The reaction admixture was kept in the darkness for $30 \mathrm{~min}$ at $28^{\circ} \mathrm{C}$. The control experiment was carried out as above without test samples. The DPPH antioxidant activity was ascertained by determining the absorbance, at $517 \mathrm{~nm}$ operating the UV-VIS spectrophotometer. The reduction of DPPH radical in activator was computed relative to the measured absorbance of the control applying the subsequent equation (1):

Scavenging effect $\%=\frac{\mathrm{Ao}-\mathrm{A} 1}{\mathrm{Ao}} * 100$ 
Where $A_{0}$ is the absorbance of the controller reaction, and $A_{1}$ is the absorbance in the existence of the tests or standards.

\section{$\mathrm{H}_{2} \mathrm{O}_{2}$ Scavenging Activity}

$\mathrm{H}_{2} \mathrm{O}_{2}$ solution $(40 \mathrm{mM})$ was made in buffer phosphate $(\mathrm{pH} 7.4)$. Various dilutions $(250,500$, 750 and $1000 \mathrm{~g} \mathrm{ml}^{-1}$ ) of the prepared compounds (or ascorbic acid) were supplemented to the $\mathrm{H}_{2} \mathrm{O}_{2}$ liquid $(0.6 \mathrm{ml}, 40 \mathrm{mM})$. The absorbance of $\mathrm{H}_{2} \mathrm{O}_{2}$ at $230 \mathrm{~nm}$ was revealed after $10 \mathrm{~min}$. in contradiction of a blank solution having phosphate buffer lacking $\mathrm{H}_{2} \mathrm{O}_{2}^{22}$. The $\mathrm{H}_{2} \mathrm{O}_{2}$ proportion inactivating activity was estimated applying equation (1).

\section{(FRAP) Ferric Reducing Antioxidant Power Assay}

The method suggested by Muss ${ }^{23}$ was applied to establish the antioxidant action through FRAP with certain minor adjustments. The FRAP component was made fresh, as in the use of 300 $\mathrm{mM}$ acetate buffer, $\mathrm{pH} 3.6\left(3.1 \mathrm{~g} \mathrm{C}_{2} \mathrm{H}_{3} \mathrm{NaO}_{2}\right.$. $3 \mathrm{H}_{2} \mathrm{O}$, with $16 \mathrm{ml}$ glacial acetic acid is adjusted up to $1: 1$ with DW; $10 \mathrm{mM}$ of TPTZ, in $40 \mathrm{mM} \mathrm{HCl}$; and $20 \mathrm{mM} \mathrm{FeCl}{ }_{3} \cdot 6 \mathrm{H}_{2} \mathrm{O}$ are mixed in a ratio of 10:1:1 followed by incubation at $37^{\circ} \mathrm{C}$ for 10 min. prior to the analysis to allow the reagent working time. About $1 \mathrm{ml}$ of FRAP substance was supplemented to $10 \mu \mathrm{l}$ of each compound after the addition of the FRAP reagent, the plates were preserved for $30 \mathrm{~min}$. at ambient condition and the absorbance of the blue complex (ferrous tripyridyltriazine) was formed from the reaction. All the data were taken in triplicates. The Trolox standard calibration curve was established by plotting the curves of various concentrations in methanol (0.00625-0.2 $\mathrm{mg} / \mathrm{ml}$ ) against absorbance (at $595 \mathrm{~nm}$ using UV-Vis spectrophotometer see Fig. $\left.{ }^{26}{ }^{26}\right)$. The calibration equation found for Trolox was $y=a x+b\left(r^{2}=0.999\right)$, where $y$ is the optical density at $593 \mathrm{~nm}$ and $\mathrm{x}$ is the concentration ( $\mathrm{mg} /$ $\mathrm{ml}) \mathrm{a}, \mathrm{b}$ is the constant, $r^{2}$ is the confidence of coefficient. The findings were reported in $\mathrm{mg}$ Trolox equivalents/g of synthesis compound. The ferric reducing antioxidant power was estimated applying the subsequent method: $\mathrm{FRAP}=(\mathrm{C} \times \mathrm{V}) / \mathrm{M}$ where FRAP $=$ the ferric reducing antioxidant power, $\mathrm{mg} / \mathrm{g}$ compound, in TE; $\mathrm{C}=$ the concentration of Trolox ascertained from the standardization curve, $\mathrm{mg} / \mathrm{mL}$; $\mathrm{V}=$ the volume of compound solution, $0.1 \mathrm{~mL} ; \mathrm{M}=$ the weight of synthesis compound, 0.0001 gram.

\section{Arithmetical analysis}

Data obtained were presented as mean \pm SD and the arithmetical significance of variances was established using one-way assay of variance (ANOVA) by the SPSS 17.0 arithmetical software package. Variances were reflected significant at $P<0.05$. The significances are represented as mean $\pm S D(n=3)$.

\section{RESULTS AND DISCUSSION}

\section{Antioxidant assay}

Antioxidant activity of prepared compounds was achieved manipulating different in vitro tests against 2,2-Diphenyl-1-picrylhydrazyl (DPPH) radical, hydrogen peroxide) inactivating and (FRAP) ferric-reducing antioxidant strength test.

\section{DPPH Antioxidant Activity of Compounds (1-4)}

The function of an antioxidant is to eliminate free radicals. One significant assumption of such elimination is by providing hydrogen to FR (free radicals) in its conversion to inactive type 20. The hydrogen addition would eliminate the single electron aspect, which is liable for radical reactivity. Free radicals have been a topic of considerable concern between specialists in the preceding decade. The antioxidant actions of compounds (1-4) were evaluated in vitro utilizing DPPH $(1,1-$ Diphenyl-2-picrylhydrazyl radical radical inactivating methods. Gallic acid was applied as the standard. Donating hydrogen activity, as estimated using DPPH radicals as a hydrogen acceptor, revealed that considerable correlation might be observed linking the concentration of the recently synthesized compound and the inhibition rate. DPPH molecules (1-4) have been proved to diminish the established radical. As indicated by Fig. (1) the prepared compounds $1,2,3$, and 4 possess $61 \pm 0.6 \%$, $86.3 \pm 1 \%, 85 \pm 0.5 \%$, and $71.2 \pm 0.8 \% \mathrm{DPPH}$ radicalinactivating action. The compounds (1, 2, and 3) contain the $\mathrm{N}-\mathrm{H}$ group, which enables hydrogen atom transfer (HAT) to the DPPH free radical to provide a resonance-stabilized radical. The scavenging influence enhanced with rising concentrations of samples. In the DPPH technique, the highest antioxidant effect was $90 \pm 1 \%$ at a strength 1000 
$\mu \mathrm{g} / \mathrm{mL}$ for compound (2), and the least inactivating power was $26.1 \pm 0.5 \%$ at $250 \mu \mathrm{g} / \mathrm{mL}$ concentration for compound (1). Fig. (2) shows the proposed mechanism for compounds, specifically, 2-amino4-(4-bromophenyl)-5-oxo-4, 5-dihydro pyrano (3, 2-c) chromene-3-carboxylic acid (2), and 3-amino2-((4-bromophenyl)(2-oxo-2H-chromen-3-yl) methyl) acrylic 2-chloro acetic anhydride (3).
Table 1: DPPH antioxidants activity of comp (1-4)

\begin{tabular}{ccc}
\hline Comp NO & $\mathrm{H}_{2} \mathrm{O}_{2}$ inhibition \%SD \\
& $100 \mu \mathrm{g} / \mathrm{ml}$ & $\mathrm{IC}_{50} \pm \mathrm{SEM}$ \\
\hline 1 & $61 \pm 0.6 \%$ & $31 \pm 0.2 \%$ \\
2 & $86.3 \pm 1.0 \%$ & $41.3 \pm 1 \%$ \\
3 & $85 \pm 0.5 \%$ & $41 \pm 0.8 \%$ \\
4 & $71.2 \pm 0.8 \%$ & $26.4 \pm 0.5 \%$ \\
\hline
\end{tabular}

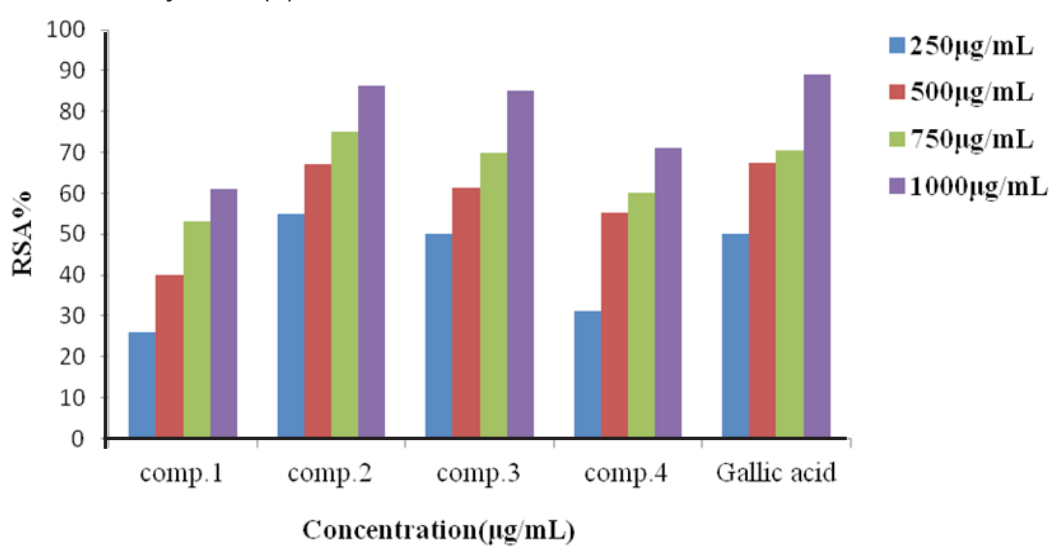

Fig. 1. Evaluation of antioxidant properties by DPPH assay for compounds (1-4)

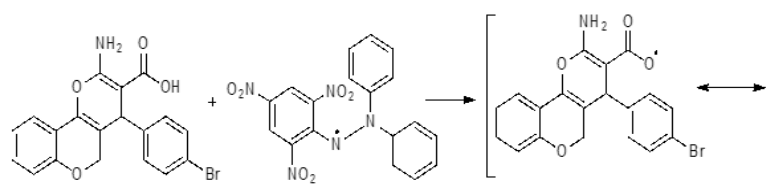

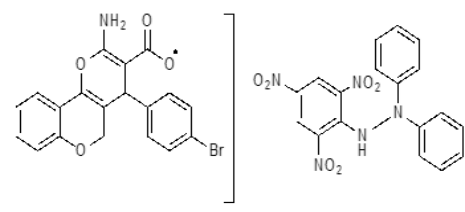

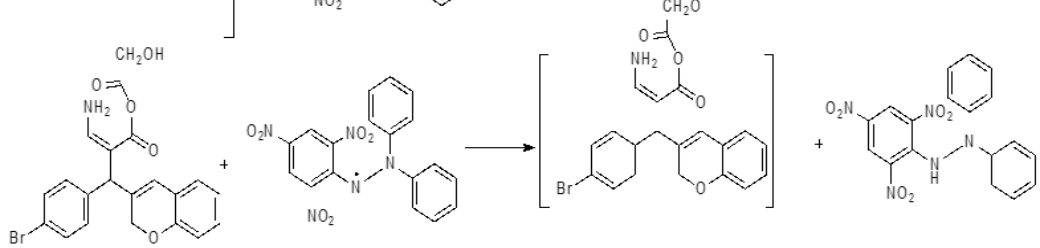

Fig. 2. The schematic mechanism between DPPH FR (free radicals) and compounds 2 and 3

\section{$\mathrm{H}_{2} \mathrm{O}_{2}$ Scavenging Capacity}

Hydrogen peroxide intact isn't extremely reactive, but the compound can occasionally be noxious to the cell due to the subsequent hydroxyl radical in cells ${ }^{24}$. Thus, the elimination of $\mathrm{H}_{2} \mathrm{O}_{2}$ is very significant for antioxidant protection in the cell. The inactivating ability of prepared compounds on $\mathrm{H}_{2} \mathrm{O}_{2}$ equaled with ascorbic acid as a reference compound is shown in Fig. 3 the coumarin compounds were able of inactivating $\mathrm{H}_{2} \mathrm{O}_{2}$ in a concentration-dependent fashion. Results display that $\mathrm{H}_{2} \mathrm{O}_{2}$ scavenging actions of compounds 2 and 3 are higher than that of the standard, and the values are $80 \pm 1.0 \%$, and $81.5 \pm 1.5 \%$, respectively. Compounds 1 and 4 show scavenging activity on hydrogen peroxide with lower value compared with ascorbic acid.

Table 2: $\mathrm{H}_{2} \mathrm{O}_{2}$ scavenging activity of comp (1-4)

\begin{tabular}{|c|c|c|}
\hline Comp NO & $\begin{array}{c}\mathrm{H}_{2} \mathrm{O}_{2} \text { inhibition \%SD } \\
100 \mu \mathrm{g} / \mathrm{ml}\end{array}$ & IC50 \pm SEM \\
\hline 1 & $60 \pm 0.5 \%$ & $29 \pm 0.5 \%$ \\
\hline 2 & $80 \pm 1.0 \%$ & $39.4 \pm 0.3 \%$ \\
\hline 3 & $81.5 \pm 1.5 \%$ & $40 \pm 0.6 \%$ \\
\hline 4 & $54.2 \pm 1.1 \%$ & $26.4 \pm 0.8 \%$ \\
\hline
\end{tabular}




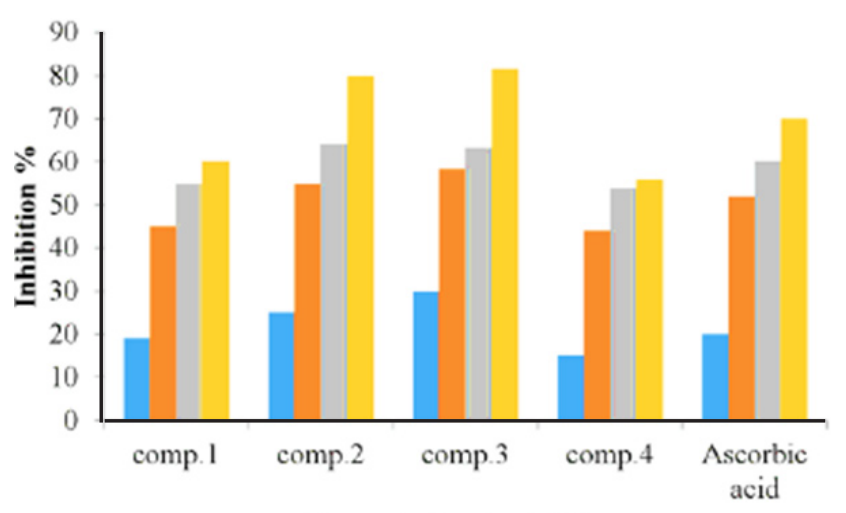

$$
\begin{aligned}
& =250 \mu \mathrm{g} / \mathrm{mL} \\
& =500 \mu \mathrm{g} / \mathrm{mL} \\
& =750 \mu \mathrm{g} / \mathrm{mL} \\
& =1000 \mu \mathrm{g} / \mathrm{mL}
\end{aligned}
$$

Concentration $(\mu \mathrm{g} / \mathrm{mL})$

Fig. 3. Influence of compound 1-4 on hydrogen peroxide

\section{Ferric Reducing Ability Power (FRAP)}

The antioxidant potential of all compounds was ascertained by a FRAP test. The FRAP assessment was revealed as an equivalent of compounds ( $\mathrm{mg} / \mathrm{g}$ of standard antioxidant Trolox). The FRAP test estimated the potency of a compound to reduce the ferric 2,4,6-Tri(2-pyridyl)$\mathrm{s}$-triazine complex to the stained ferrous complexes compound. FRAP results are acquired by relating the absorbance alteration at $593 \mathrm{~nm}$ in assay reaction admixtures with those having ferrous ions in identified concentrations. In general, the reducing properties of these sets of compounds largely rely on the sum and position of hydrogen-donor hydroxyl clusters on the aromatic group of phenolic compounds; in addition, the properties are influenced by other aspects, such as $\mathrm{H}$-donor groups $(-\mathrm{NH},-\mathrm{SH})^{25}$, which apply their effect by destroying the free radical series via providing a hydrogen atom ${ }^{26,27}$. The FRAP test considers the antioxidants specimen as a reluctant in a redox-associated colorimetric effect ${ }^{28}$ following the equation:

FRAP: $\mathrm{Fe}(\mathrm{TPTZ}){ }_{2}^{3+}+\mathrm{ArOH} \rightarrow \mathrm{Fe}(\mathrm{TPTZ}){ }_{2}{ }^{2+}+\mathrm{ArO} .+\mathrm{H}^{+}$ FRAP: $\left[\mathrm{Fe}(\mathrm{TPTZ})_{2}\right]^{2+}$ (Ferrous tripyridyl triazine cation)

Several synthetic and naturally existing coumarins display possible antioxidant activity. Therefore, the antioxidant influence of coumarin derivatives 1-4 was assessed utilizing FRAP test in contrast to Trolox. The linearity of FRAP (dose-response curve) for conventional solutions is presented in Fig. (4). The values of the FRAP test are stated in Table (1), and ferric reducing ability was represented as the concentrations of antioxidant as FRAP value $(\mathrm{mg} / \mathrm{g})$. Depending on results, compounds 2 and 3 revealed considerable antioxidant activity compared with Trolox owing to the existence of the $\mathrm{NH}_{2}$ group, which donates a hydrogen atom, in the structure of these compounds. However, the remaining compounds show poor antioxidant power.

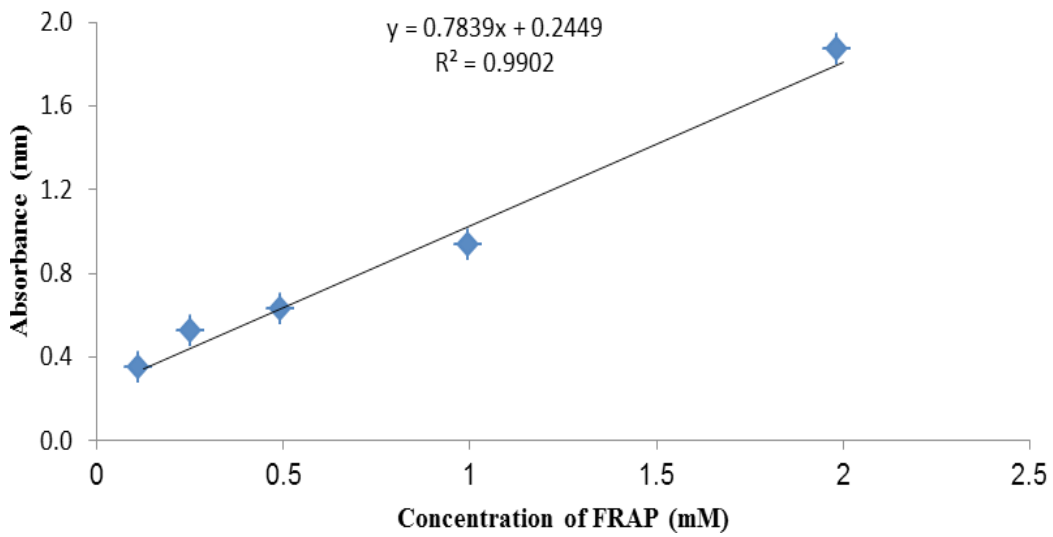

Fig. 4. Linearity of FRAP for stock solutions (Trolox) 
Table 1: FRAP antioxidant activities of prepared compounds

\begin{tabular}{cc}
\hline Compound & FRAP value $(\mathrm{mg} / \mathrm{g})$ \\
\hline 1 & 10.4 \\
2 & 41.6 \\
3 & 60.2 \\
4 & 9.1 \\
\hline
\end{tabular}

\section{CONCLUSION}

The preparation and characterization of coumarin derivatives are of considerable interest owing to their potential for various applications based on their biological activity. A series of 4-hydroxy coumarin compounds were successfully synthesized by conventional methods. The recently prepared molecules were described by using elemental analysis $(\mathrm{CHN})$ and spectroscopic methods (IR and ${ }^{1} \mathrm{H}$ and ${ }^{13} \mathrm{C}$ NMR). The scavenging activities of prepared coumarins compounds were verified by utilizing hydrogen peroxide test $\left(\mathrm{H}_{2} \mathrm{O}_{2}\right)$, DPPH antioxidant examines, and FRAP assess. Results indicate that DPPH give the best antioxidant activity observed for compound $2(86.3 \pm 1 \%)$ followed by compounds $3(85 \pm 0.5 \%)$. The new coumarins hold greater scavenging activity compared with vitamin C, gallic acid, and Trolox as standards.

\section{ACKNOWLEDGMENT}

We are grateful to the staff membered at pharmaceutical chemistry department at Kufa University for kind help \& support.

\section{REFERENCES}

1. Elhafez, O.M.A.; Khrisy, E.E.D.A.M.E.; Badria, F. et al. Synthesis and biological investigations of new thiazolidinone and oxadiazoline coumarin derivatives Arch. Pharm. Res., 2003, 26, 686-696.

2. Basanagouda, M.; Kulkarni, M.V.; Sharma, D. Synthesis of some new 4-aryloxmethyl coumarins and examination of their antibacterial and antifungal activities J. Chem. Sci., 2009, 121, 485-495.

3. Parfenov, É.A.; Smirnov, L.D., \& Trapkov, V.A. Synthesis and antiulcer activity of copperand zinc-containing coumarin antioxidants. Pharm. Chem. J., 2005, 30, 445-447;

4. Darwish, E.S.; Fattah, A.M.; Abdel Attaby, F.A.; Al-Shayea, O.N. Synthesis and Antimicrobial Evaluation of Some Novel Thiazole, Pyridone, Pyrazole, Chromene, Hydrazone Derivatives Bearing a Biologically Active Sulfonamide Moiety. Int. J. Mol. Sci., 2014, 15, 1237-1254.

5. Al-Amiery, A. A.; Al-Majedy, Y.K.; Kadhum, A. A. H., \& Mohamad, A. B. Novel macromolecules derived from coumarin: synthesis and antioxidant activity. Sci. Rep., 2015, 5, 11825.

6. Aiyelabola, T.; Akinkunmi, E.; Obuotor, E.; Olawuni, I.; Isabirye, D. \& Jordaan, J. Synthesis Characterization and Biological Activities of Coordination Compounds of 4-Hydroxy-3-nitro-2H-chromen-2-one and Its Aminoethanoic Acid and Pyrrolidine-2carboxylic Acid Mixed Ligand Complexes.
Bioinorg. Chem. Appl., 2017, 2017, 6426747.

7. Shaimaa A. M.; Abdelbasset A. F.; Magda N.A. N.; Atif S. T. Synthesis, molecular modeling and anticancer activity of new coumarin containing compounds. Saudi Pharm. J., 2017, 25, 873-883.

8. Marchenko, M.M.; Kopyl'chuk, G.P.; Shmarakov, I.A. Synthesis and antitumor activity of 5-(5',6'-benzocoumaro-3'-yl)methyl aminouracil hydrobromide and its liposomal medicinal form. Pharm. Chem. J., 2006, 40, 296. Fereldoon S. Antioxidants for food preservations. Woodhead Publishing elseiver, UK., 2015, 276, 238-241.

9. Miri, R.; Saadati, H.; Ardi, P.; Firuzi, O. Alterations in oxidative stress biomarkers associated with mild hyperlipidemia and smoking. Food Chem. Toxicol., 2012, 50, 920-926.

10. Grešner, P., Swiercz, R., Król, M.B. Does the Low-level occupational exposure to volatile organic compounds alter the seasonal variation of selected markers of oxidative stress? A case-control study in nail technicians. J Occup Med Toxicol., 2016, 11, 36.

11. Sies, H., Berndt, H. C., and Jones, D. P. Oxidative Stress. Oxidative stress. Annu. Rev. Biochem., 2017, 86, 715-748.

12. Mehrdad, A.; Javad, K.; Mahdi, K.; Farhad, A.; Mahnaz, A. Comparison of total phenolic and antioxidant activity of different Mentha spicata and M. longifolia accessions. Ann. Agric. Sci., 2016, 61, 175-179. 
13. Al-Azzawie, H.F.; Alhamdani, M.S. Hypoglycemic and antioxidant effect of oleuropein in alloxan-diabetic rabbits. Life Sci., 2006, 78, 1371-7.

14. Khurana, J.M.; Kumar, S. Tetrabutylammonium bromide (TBAB): a neutral and efficient catalyst for the synthesis of biscoumarin and 3, 4-dihydropyrano [c] chromene derivatives in water and solvent-free conditions. Tetrahed. Lett., 2009, 50, 4125-4127.

15. Divsalar, N.; Monadi, N.; Tajbaksh, M. Preparation and Characterization of a Molybdenum(VI) Schiff Base Complex as Magnetic Nanocatalyst for Synthesis of 2-Amino-4H-benzo[h]chromenes. J. Nanostruct., 2016, 6, 312-321.

16. Reid, A.E.; Kim, S.W.; Seiner, B.; Fowler, F.W.; Hooker, J.; Ferrieri, R.; Babst, B. Fowler, J.S. Radiosynthesis of C-11 labeled auxin (3-indolyl[1-11C]acetic acid) and its derivatives from gramine. J. Label Compd. Radiopharm., 2011, 54, 433-437.

17. Serban, G. 5-Arylamino-1, 3, 4-thiadiazol-2yl acetic acid esters as intermediates for the synthesis of new bisheterocyclic compounds. Farmacia., 2015, 63, 146-149.

18. Kadhum, A.A.H; Al-Amiery, A.A.; Musa, A.Y.; Mohamad, A.B. The Antioxidant Activity of New Coumarin Derivatives. Int. J. Mol. Sci., 2011, 12(9), 5747-5761.

19. Abdul Amir, H. K.; Ahmed, A. A.; Mukaram, S.; AbuBakar, M. Synthesis, structure elucidation and DFT studies of new thiadiazoles. Int. J. Phys. Sci., 2011, 29, 6692 - 6697.

20. Ahmed, A.A.; Abdul Amir, H. K.; Hasan, R.O.; Abu Bakar, M. Synthesis and Antioxidant Activities of Novel 5-Chlorocurcumin, Complemented by Semiempirical Calculations.
Bioinorg. Chem. Appl., 2013, 2013, 354982.

21. Musa, K. H.; Abdullah, A.; Jusoh, K.; Subramaniam, V. Antioxidant Activity of PinkFlesh Guava (Psidium guajava L.): Effect of Extraction Techniques and Solvents. Food Anal. Methods., 2011, 4, 100-107.

22. Goufo, P.; Trindade, H. Rice antioxidants: phenolic acids, flavonoids, anthocyanins, proanthocyanidins, tocopherols, tocotrienols, $\gamma$-oryzanol, and phytic acid. Food Sci. Nutr., 2014, 2, 75-104.

23. Prakash J.D.; Prakash J.; Lakshmi A.J.;FatihY. Antioxidant properties of fresh and processed Citrus aurantium fruit. Cogent Food Agric., 2014, 2, 2016.

24. Prasad, K.N.; Chew, L.Y.; Khoo, H.E.; Kong, K.W.; Azlan, A. Ismail A. Antioxidant Capacities of Peel, Pulp, and Seed Fractions of Canarium odontophyllum Miq. Fruit. J. Biomed. Biotechnol., 2010, 2010, 871379.

25. Kumar, S.; Sharma, S., Vasudeva N. Review on antioxidants and evaluation procedures. Chin. J. Integr. Med., 2017,1-7.

26. Yehye, W.A.; Rahman, N.A.; Ariffin, A.; Abd Hamid, S.B.; Alhadi, A.A.; Kadir, F.A.; Yaeghoobi, M. Understanding the chemistry behind the antioxidant activities of butylated hydroxytoluene (BHT): a review. Eur. J. Med. Chem., 2015, 101, 295-312.

27. Comparison of ABTS, DPPH, FRAP, and ORAC assays for estimating antioxidant activity from guava fruit extracts Kriengsak, T.; Unaroj, B.; Kevin, C.; Luis, C-Z.; David, H. B. Comparison of ABTS, DPPH, FRAP, and ORAC assays for estimating antioxidant activity from guava fruit extracts. J.Food Compost. Anal., 2006, 19, 669-675. 